\title{
Locating an indigenous ethos in ecological performance
}

Article

Accepted Version

Woynarski, L. (2015) Locating an indigenous ethos in ecological performance. Performing Ethos, 5 (1 \& 2). pp. 1730. ISSN 1757-1987 doi: https://doi.org/10.1386/peet.5.12.17_1 Available at https://centaur.reading.ac.uk/67196/

It is advisable to refer to the publisher's version if you intend to cite from the work. See Guidance on citing.

To link to this article DOI: http://dx.doi.org/10.1386/peet.5.1-2.17_1

Publisher: Intellect Ltd

All outputs in CentAUR are protected by Intellectual Property Rights law, including copyright law. Copyright and IPR is retained by the creators or other copyright holders. Terms and conditions for use of this material are defined in the End User Agreement.

\section{www.reading.ac.uk/centaur}

\section{CentAUR}

Central Archive at the University of Reading

Reading's research outputs online 


\title{
Locating an Indigenous Ethos in Ecological Performance \\ Lisa Woynarski \\ Royal Central School of Speech and Drama
}

Keywords: Indigenous ecology, performance and ecology, postcolonial ecocriticism

\begin{abstract}
:
Stories are powerful forms of representation and cultural imagery in many indigenous cultures, and performance is a site where these stories are shared, revealed and enacted, making it a powerful site of cultural imagery for indigenous ecological knowledges and cosmologies. I argue that an indigenous ecological ethos is a necessary addition to thinking about performance and ecology, one that resists patronising and simplistic stereotypes of the 'eco-Indian' and acknowledges diverse, complex and evolving epistemologies. Drawing on Huggan and Tiffin's (2010) postcolonialism ecocriticism, as well as May (2014) and Kuppers (2014) experience as non-indigenous scholars and practitioners, this article considers the role postcolonial ecology might play in the field of performance and ecology and how non-indigenous scholars and theatre-makers might engage with it. I suggest strategies for locating an indigenous ecological ethos, through examples of contemporary performance. Däwes (2014), Nolan (2014), Howe (1999) and Halba (2014) provide critical reflections on indigenous performances specifically attuned to ecological concerns. I draw on plays and performances which highlight the inseparability of land, identity and more-than-human (Salmon is Everything, NK603: Action for Performer \& e-Maiz, Woman for Walking); work that is non-linear and recognizes the simultaneity of past, present and future (Burning Vision, Chasing Honey); and work that takes up ecological justice issues (Sila). These aspects suggest ways of locating an indigenous ecological ethos and developing a more mutlivocal and inclusive field of performance and ecology.
\end{abstract}

\section{Introduction: Stories, representation and living theatre}

Choctaw scholar LeAnne Howe (1999) writes of Native stories as living theatre, which make connections and interrelations between peoples, time and places, as stories are performances of histories, beliefs and epistemologies. 'Native stories are power. They create people. They author tribes' (118). Stories create, shape and reinforce ideas, cosmologies, and relations to the world, and have effects on understanding the past, present and future. Performance can be a powerful site for the intersection of ecology and postcolonialism because of the power of indigenous' stories as living theatre and the effects of cultural images and representation. Indigenous viewpoints may offer a different way of thinking about ecological performance, and performance may be a way of resisting the reductive representations of indigenous peoples. However, as Birgit Däwes (2014) suggests, this remains an undertheorized area as only recently has the convergence of indigenous epistemologies, ecology and representations within culture been taken up as a topic of scholarship. The problematic colonial association with 'research' is inherent here, as Māori scholar Linda Tuhiwai Smith (2012) writes " "research" is probably one of the 
dirtiest words in the indigenous world's vocabulary' as it 'is inextricably linked to European imperialism and colonialism' (1). Mindful of this position, this article will critically engage with indigenous knowledges within the field of performance and ecology, which broadly brings ecological thinking to bear on performance criticism, dramaturgy, production, and performance scholarship.

I would like to foreground, from the beginning, that I do not identify as indigenous. I am a white Canadian (with Belgian, Ukrainian, Polish and British heritage) who currently resides in the United Kingdom, and as such this critique of the western academy is self-reflexive. I am implicated in the lacunae of critical indigenous voices in the field performance and ecology. My aim here is not to appropriate indigenous ideas or speak for any group of people, rather I want to think critically about some of the underlying ethnocentric assumptions made about ecology, where and how indigenous scholarship is located in the field, and ways of thinking about an indigenous ecological ethos in performance. Acknowledging Jodi Byrd's (2006) critique of indigenous knowledges being subsumed into colonialist discourses, I am suggesting strategies for locating an indigenous ethos in performance that is grounded in complex and dynamic indigenous epistemologies. However, this theorization is open to the same criticisms of re-inscribing implicit imperial values given the context of the discourse of performance and ecology and the form of this article. Currently, this discourse has been primarily developed in the western academy, which too rarely includes indigenous scholars or takes indigenous ontologies into account. This is not to dismiss the work of indigenous scholars within the academy (or the work of non-indigenous scholars on postcolonialism or de-colonization), rather to point out the way in which the system of knowledge legitmation tends to exclude indigenous epistemologies. Part of this work, then, is to consider how non-indigenous scholars and performance-makers (such as myself) engage with an indigenous ecological ethos without reaffirming colonial assumptions, with an understanding of 'how the cultures and histories of those whose identity has been construed as "Other" imagine new stories that offer us the materials for a more inclusive environmentalism and a more multicultural ecocriticism' (Adamson 2001: xix). The inherent interconnections between colonialism and ecological subjugation are too prevalent not to be considered by the field in general, and as Smith writes, the responsibility to make change is in both the non-indigenous and indigenous worlds' (2012: xii). Locating an indigenous 
ethos in performance is needed to develop a more inclusive and multivocal field of performance and ecology.

In the following, I will examine performances that engage with indigenous ecological thinking with respect to three interrelated elements: the inseparability of humans, land and the more-than-human worldii; non-linear timescales and histories; and environmental justice. Postcolonial scholars DeLoughrey and Handley (2011) argue for the potential of literature to foreground, through imaginative means, the political and ethical force of an ecological worldview informed by postcolonial theory. I argue that performance has this same opportunity to engage an ecological imagination, grounded in a nuanced ethos that is relational, complex and multivocal. Of course there are many traditions and cultures within the ambiguous label of 'indigenous' (as well as those postcolonial people who do not identify as indigenous), but there are certainly some commonalities, particularly in the material effects of colonialism, such as systemic oppression and land loss to name only a few. An indigenous ecological ethos is a necessary addition to performance and ecology, while resisting the eco-Indian stereotype and recognizing that although indigenous peoples and cultures avoided some of the western-centric exploitation of the more-thanhuman world, this is not a universalising or simplistic harmony. In acknowledging the complex and dynamic nature of indigenous ecological knowledges, this article will reflect on a few specific examples based on First Nations, Inuit and Métis peoples of Turtle Island (North America), indigenous peoples of Mexico and Central America, Māori of Aotearoa (New Zealand) and Aboriginal Australians. The performance examples I will draw on include works which highlight the inseparability of land, identity and more-than-human (May's Salmon is Everything, Luna's NK603: Action for Performer \& e-Maiz); work that is non-linear and recognises the simultaneity of past, present and future (Clements's Burning Vision, Shamas's Chasing Honey); and work that takes up ecological justice issues (Bilodeau's Sila, Evans' Oil City). With these performances, I will consider how locating an indigenous ethos may provide a way of critiquing and/or resisting the power structures, dominant historical narratives and anthropocentrism that have led to the current ecological crisis.

Of course there is an inherent paradox (and irony) in the writing and form of this article. It falls within the same system of knowledge legitimation that it seeks to critique. However, this paradox of writing within a western academic tradition may produce a generative tension. I am inspired by Sandy Grande's (2004) Red 
pedagogy, which seeks out ways in which American Indian education and knowledges can open up and diversify critical theory while in turn the western academy may open new modes of inquiry for American Indian education (28). These different epistemic frames are engaged with horizontally, rather than hierarchically, not towards assimilation of knowledge but towards de-colonization, recognition of difference and multiple ways of knowing. It is from this position that I engage with an indigenous ethos.

\section{Postcolonialism and ecology}

My use of the term 'postcolonialism' here is a way of referencing a field of study around the effects of colonialism and colonization, while mindful of the tensions inherent in the prefix of 'post'. I do not mean to suggest that we are beyond 'colonialism', rather that the material effects and systemic mindset of imperialism is still evident today, albeit in different forms. However, like performance and ecology, postcolonialism exists within an academic context and discourse that does not necessarily value indigenous ways of knowing or knowledge production (Smith 2012: 24). I argue that any thinking about ecology has to include consideration of the power structures, political agendas and ethical assumptions that produce the ecological crisis. The term then is helpful in identifying the field of study with overlapping concerns: postcolonial ecology.

The intersection of ecological thought and postcolonial theory can critically reveal the way history has been shaped by colonial assumptions about relationships to the more-thanhuman world. Graham Huggan and Helen Tiffin explain the relationship in Postcolonial Ecocriticism (2010): 'postcolonialism's concerns with conquest, colonization, racism and sexism, along with its investments in theories of indigeneity and diaspora and the relations between native and invader societies and cultures, are also the central concerns of animal and environmental studies' (6). Ecology and postcolonialism are so connected that Pablo Mukherjee (2011) contends that each field is necessary to an understanding of the other as the 'global conditions of colonialism and imperialism (let us call it postcolonial studies) cannot but consider the complex interplay of environmental categories such as water, land, energy, habitat, migration' (177-178) which are imbricated in social and political ideas of nation, society and art, including literature, theatre and visual arts. These twin fields cannot be considered in isolation as their historical development and primary concerns are interwoven. 
Anthropocentrism, environmental racism and sexism are tied to colonial assumptions grounded in a history of ecological subjugation. Huggan and Tiffin describe environmental racism (a form of ecological imperialism) as a twofold phenomenon: a sociological one which results in 'the environmentally discriminatory treatment of socially marginalized or economically disadvantaged peoples' and the material phenomenon of transferring environmental problems to a 'foreign outlet' through the 're-routing of First World commercial waste' for example (4). This reinforces what Val Plumwood (2002) refers to as 'hegemonic centrism'. In Plumwood's interpretation, 'hegemonic centrism' is the solipsistic and egocentric viewpoint that justifies and underpins sexism, racism and colonialism, which intersect to reaffirm each other, and have all been used historically to legitimate ecological exploitation. Plumwood contends that idea is linked to a naturalized anthropocentrism that has historically justified European colonialism where 'foreign', indigenous people are classified as animalistic and uncivilized (as animals), enacting both racism and speciesism. The effect of this type of anthropocentrism leads to ecological injustices (such as the Alberta tar sands, land grabs, water contamination, fracking) by governments and corporations who do not take indigenous epistemologies seriously, coding them as 'primitive' and a hindrance to technology, 'progress' and capitalism. 'In assuming a natural prioritization of humans and human interests over those of other species on earth, we are both generating and repeating the racist ideologies of imperialism on a planetary scale' (Huggan and Tiffin 6). I suggest that postcolonial ecology, then, offers ways of critically thinking about ethnocentric ideas of ecology, as it seeks to address the underlying assumptions, hierarchies and power structures that have lead to both the marginalization of indigenous people and the Earth.

The effects of these assumptions are epitomized in the patronizing stereotype of the 'ecological Indian', which is, I suggest, one of the ways cultural representations have reinforced colonialist ideologies. The romanticized images of the eco-Indian or ecoAboriginal, which impose a primitive, simplistic, harmonious relationship to land and environment, have provided convenient and forceful ways of imposing agendas of displacement and marginalization (Däwes and Maufort 2014:12), suggesting a type of ecological nostalgia, which might also be considered as a reframing of colonial notions of 'otherness'. The patronizing and reductive trope of the eco-Indian is neither historically accurate (Krech 1999) nor premised on a complex understanding of indigenous ontologies. The trope takes complex cosmologies and codes them as 'naïve' or 'rustic', 
effectively dismissing indigenous ecological knowledges as irrelevant or 'quaint' and perpetuating hegemonic centrism.

Although there has been some thoughtful scholarship recently that addresses the intersection of postcolonial ecology and performance, the area broadly remains undertheorized. The recent landmark collection, Enacting Nature: Ecocritical Perspectives on Indigenous Performance (2014), is one of the first to seriously address this topic within the western academy. Based on North American and Oceania perspectives, the collection features both indigenous and non-indigenous scholars thinking through a number of different performance works. In the introduction, Däwes and Maufort acknowledge that 'in spite of the fast expanding field of ecocritical practice...much remains to be done at the theoretical sites of discussion' (13). In engaging with indigenous work, the 'EcoCentrix: Indigenous Arts, Sustainable Acts' (2013) exhibition in London, was presented by Helen Gilbert's (Royal Holloway) 'Indigeneity in the Contemporary World' research project, and featured a range of work from contemporary indigenous artists from around the world. Some theatre and performance scholarship on postcolonial ecology has also begun to emerge with a number of articles and essays recently published. Among this list is Gray's ‘Bringing Blood to Ghosts: English Canadian Drama and the Ecopolitics of Place’ (2012), May's 'Kneading Marie Clements' Burning Vision’ (2010), 'Indigenous Theatre in Global Times: Situated Knowledge and Ecological Communities in Salmon Is Everything and Burning Vision' (2014), and Salmon is Everything: Community-Based Theatre in the Klamath Watershed (2014b), all of which are promising developments in postcolonial ecology and indigenous ecological knowledge in performance, although there is undoubtedly more scholarship needed to take seriously the diverse and complex dynamics of this area.

\section{Locating non-indigenous scholars and artists in indigenous performance}

Postcolonialism, ecocriticism and performance and ecology exist within the western academy and are therefore steeped in imperialist language and knowledge legitimation (Smith 2012, Byrd 2006). The question then becomes how do non-indigenous scholars and/or artists engage with indigenous cosmologies and ecological epistemologies without reasserting the power structures of colonialism or invoking the eco-Indian stereotype? 
Community performance artist and researcher, Petra Kuppers (2014), has argued for reading strategies of transnational performance practices in indigenous/settler collaborations, specifically citing 'relational living, in the flow of history, speaking from webs of more than one voice, and attending to gaps' (5). By positioning herself in a living relationship with the performance practices she encountered, Kuppers attempts to decentre colonialist-marked methods of interpretation, of truth seeking and performance criticism. Similarly, my own way into this research, as a non-indigenous person, is not through claims of authority, but rather through suggestions of the way relational, complex and heterogeneous ecological knowledges may offer ways of thinking about and critiquing ecological resilience in the age of the Anthropocene. Through stories as performance and living theatre, I aim to suggest strategies of locating an indigenous ethos within the discourse of performance and ecology.

May (2014b) described her experience of Native/non-Native collaboration for the community-based performance, Salmon is Everything, as a complicated education. In 2002 there was an unprecedented fish kill, on the Lower Klamath River, which was harmful to local people who depended on the river for their livelihood: Native tribes who fished salmon, commercial fisherman, and farmers and ranchers who depended on the water (May 2014a: 201). May wanted to initiate a performance project involving the community because she thought it would be a way to bring out the Native voices which were seemingly absent from the public discussion of the crisis. May writes that the first meeting to discuss the project at Humboldt State University in California an Indian elder stopped her description of the project, saying 'What's all this talk about telling an Indian story when we're sitting in a classroom of a racist institution?' (2014b: 104). In that moment, the elder cut to the heart of the anomaly of indigenous/non-indigenous collaborations. How can institutions and knowledge frameworks laden with western value judgments and modes of knowledge legitimation engage with indigenous ecological epistemologies in a way that is respectful and meaningful? iii $^{i}$

For May, this exchange began a process of listening to Native stories, involving Native artists and community members in the process as collaborators and consulting Native people throughout (with the caveat that the university would have no ownership over the stories shared), so that the 'end product reflected the values of the Native community' (May 104). May also writes of adjusting rehearsal schedules to 'Indian time' - not necessarily the institutional imperative of 'good time management' as 'the idea of regulated, incremental, and regimented minutes, hours, days, weeks, and so on is only 
one way of understanding and organizing time' (May 107 original emphasis). The process also included learning about Native cosmologies and spiritual life, the meaningfulness of traditional objects (not as props), and of negotiating the historical tensions between the Native tribes on the watershed (Yurok, Karuk, Hoopa Valley and Klamath Indian) and the government institutions, large-scale agricultural farmers and university researchers.

Through these tensions and learning process, the project brought performance-making strategies and techniques to bear on a controversial local ecological issue, respecting the Klamath River people's world-view while staging affective stories of the river not usually represented in mainstream public forums.

However, one of the dangers of this kind of cultural representation and stories being presented to non-indigenous audiences is placing indigenous people as 'spokesperson' or 'cultural informant'. Yvette Nolan (2014), Algonquin/Irish theatre-maker, speaks of trying to 'resist the pressure to serve as a cultural informant, a guide to the Indigenous world (view) for the non-Native traveler' (111). It is imperative for non-indigenous scholars and practitioners to think critically about the ethics of cultural representations of indigeneity, which can present a romanticised and/or homogenized culture, and to understand 'the great abyss across which we work, as Natives and non-Natives' (Nolan 111). The recognition of different world-views or cosmologies that are not 'primitive' but grounded in rich tradition while continuing to evolve as relevant knowledge is one of the ways in which we may start to cross 'the great abyss'. 'I have entered into this research mindful of the critique of generalizing and reinforcing western modes of knowledge productive, while attempting to think seriously about how indigenous ecological knowledges may contribute to, develop and fortify ecological performance.

\section{Ways of locating an indigenous ethos in performance}

Okanagan artist and activist Jeannette Armstrong (1998) writes that 'stories that are used for teaching must be inclusive of the past, present, and future, as well as the current or contemporary moment and story reality, without losing context and coherence while maintaining the drama' (194). Stories, then, are enacted and dramatic performances. May (2014) refers to stories as 'a matrix of belonging, a living tissue between past and present, between human and nonhuman communities; and in this way, stories help heal the earth and ourselves' (193). Performance is a site where these stories are shared, revealed and presented, making it a potent place to locate an indigenous ecological ethos. In the following, I suggest strategies for locating an indigenous ecological ethos in performance, 
through stories that resist the bifurcation of humans and nature, contain nonlinear histories and timescales, and take up ecological justice issues. Although separated here into three sections, these strategies are inextricably linked to each other, with gaps and overlaps between them.

\section{Inseparability of humans, land and the more-than-human}

Scholar Hilary Halba (2014) contends that Māori playwright, Witi Ihimeara's (of Te Aitangaa-Mahaki descent) Woman for Walking (2000), enacts a Māori worldview that is of an interwoven ecosystem, between human history, people and the more-than-human world (220). The Māori world, Te Ao Māori, recognises an inseparability of human and morethan-human and resists the binary of human/nature: 'human history and its relationship with the world of nature are inscribed into the self by way of whakapapa (genealogy); whakapapa charts histories of lineage - of the cosmos, elemental deities, humans and the biosphere' (Halba 2014: 219). The identity of the characters in the play, about the relocation of a Māori family, are linked to their sense of place and the ecological relations of that place.

This sense of inseparability to the land and more-than-human world, echoes the Australian Aboriginal concept of Country, which reflects the way in which ideas of ecological relationships are imbricated in ideas of the social, self and others:

Country refers to everything including the land, air, water and stories of "Dreaming", being dynamic and multilayered, forming the rules, norms and beliefs of existence between species and humans through connecting Aboriginal peoples' back to ancestral beings from the time of creation. (Kingsley et al. 2013b: 682)

Kingsley et al. go on to caution that the Aboriginal connection to land should not be romanticised or fall into the eco-Aboriginal trope, as it evolved over time, responding to current conditions in a complex and multi-dimensional way (682). Resisting the romantic stereotype, the idea of Country, or Caring for Country, is responsive and active, evolving with changing contexts and material conditions.

May and Klamath Theatre Project's Salmon is Everything (2014) highlights the cosmology of Klamath River people, which similarly links identity to place and the more-than-human. 
In the play, the inseparability of the people and the-more-than-human is illustrated by Julie, a Yurok-Karuk character who speaks of her people: 'they are the trees, the water, the fish. That the Salmon are brothers is not some kind of myth; the Salmon are not symbols of life, they are life.' (May and Klamath Theatre Project 44). To understand the Salmon as brothers positions the more-than-human not as resource but as fellow living being. The Yurok-Karuk people fish the salmon but recognize the need to do so in a way that respects the life of the salmon and sustains the salmon population for future years. This opposition to binary-making practices that separate human/nature and human/nonhuman is understood as a continuum of life. This continuum can redress the boundaries and categorizations that privilege the western conception of human and devalue the more-than-human, leading to ecological subjugation.

Violeta Luna's NK 603: Action for Performer \& e-Maiz (2014), similarly explores these connections in a different context. Using her body, she enacts the inseparability of the maize (corn) growing and land to identity and indigenous Latin American cultures while highlighting the effects of Monsanto's GMO (genetically modified organisms, broadly used to produce crop species that are drought-resistant, chemical-resistant, or have a specific appearance) intervention into the livelihood of maize farmers in Mexico. NK 603 is a maize variety that is resistant to the herbicide Round Up, also produced by Monosanto, meaning the plants can be sprayed with it without dying. Maize is both a food source and cultural source for Mexicans and other Latin Americans. For example, the growing of maize is connected to a larger Mayan cosmology and their foundational myth, and it is thought that you do not cultivate maize; rather you have a conversation with it. In performance, Luna's body is entangled with the land and its ecology, as demonstrated by a purple maize plant painted on her back. Medical tools are used to manipulate her body, and a scientist in a lab coat binds her in duck tape, restraining her. May (2010) identifies this connection of body and land as a strategy of ecological performance: 'to show what we do to the land and what we do on the land is writ in our bodies' (9). Land, identity, culture and body are all intimately connected in Mayan cosmology, an ethos Luna highlights in the piece. This work is also about ecojustice in response to the inequity of NAFTA (North American Free Trade Agreement) and the use of GM crops as monoculture. The resistant nature of the performance is clear, not only does it seeks to fight against the multinational intervention into the land, it also actively disrupts human/nature dualisms which insist on mastery over the more-than-human world. 
Many indigenous epistemologies resist the bifurcation of nature and culture and consider the interrelatedness of land, humans and well being (such as the Navajo and Māori), or humans and more-than-human (such as the Mbuti Pygmies and the Batek Negritos of Malaysia), or land and knowledge (such as with Inuit Qaujimatuqangit or Inuit knowledge). This does not mean a simplistic harmony suggested by the eco-Indian cliché. Rather, that these ecological ontologies can offer ways of resisting western-centric hegemonic assumptions about ecology, nature and resourcism.

\section{Nonlinearity in Burning Vision and Chasing Honey}

Burning Vision (2003), by Marie Clements presents a Dene worldview that manifests a temporal and spatial non-linearity. The play tells the story of the making of the first atomic bomb, tracing the history through ore. It was mined by white settlers on Dene land in the Northwest Territories of Canada, transported down the Mackenzie River, refined in Ontario before heading to test sites of the Manhattan project and finally detonating over Hiroshima (May 2010). The history is not traced in a linear order; rather it connects places, people and historical moments across time and space, through a complex web of materials and relations. 'The indigenous viewpoint from which the play is written, and which it enacts, allows for simultaneity of past, present and future, in which the spirit world co-exists with the embodied world, in which nothing is inanimate' (May 2010: 7). A Japanese fisherman feels the impact of unearthing uranium in the Northwest Territories in a different time. Materials such as flour, ore, bread, and water are animated over timescales, producing effects that reverberate over long distances. May refers to this as 'time-outside-of-time' in which 'the play makes visible a web of human agency that binds together places, people, and creatures' (6). Acknowledging this simultaneity is as strategy for considering the way in which indigenous ecological knowledges open up ways of critiquing ecological relationships, in which the material impacts of the past are felt as keenly as the ones in the present and future. This non-linear understanding of ecological effects may also foster an ethical responsibility to the future and more ecological ways of being.

The simultaneity extends to human identities, as Däwes writes, 'within these permeable spaces and temporal environments, human identities -both Native and non-Native - are constructed as fluid and flexible, far from any essentialism, and with the full responsibility of acknowledging their ecological embeddings' (2014: 41). While Burning Vision includes multiple characters from different times and cultures, it also enacts a Dene world-view in 
which communication happens over multiple timescales and spaces. The character of a Dene Seer (a medicine man) elaborated this world-view: 'we are answering each other over time and space. Like a wave that washes over everything and doesn't care how long it takes to get there because it always ends up on the same shore' (Clements 2003: 75). This non-linearity can also be a resistance to the dominant (colonialist) narrative of history, as it enacts events through an indigenous view point revealing the interconnections of people, land, and more-than-humans across time and space. Non-linearity also acknowledges the cultural construction of time keeping and organization, the prioritization of 'efficiency', which is laden with value judgments that privilege one culture over ones that may organize time differently (i.e. Indian time).

In her study of Native American drama, scholar Christy Stanlake (2009) identifies Native dramaturgy as frequently non-linear: 'like storytelling, Native plays often utilize a nonlinear, sometimes cyclical, plot structure' (23). This cyclical temporality is evident in Chickasaw artist Laura Shamas's Chasing Honey (2007), which also reflects an indigenous cosmology in which ancestors and dreams occupy a co-present time and space. The play centres on Colony Collapse Disorder (the unexplained sudden collapse of bee populations), Native American university students in a Native American Awareness Club and beekeepers. The bee's struggle for survival mirrors that of Native American culture and identity. Dreams and visions are used to highlight the way the past, present and future are operating in a non-linear way, as Yvette Nolan (2014) describes, 'in Indigenous thought, the ancestors are with us, always, all times are connected to each other, dreamtime and waking time' (111). Tradition (of beekeeping and in Native American cultures in general) and the idea of evolving (to new ways of living, new identities and ecological realities) collide in the play. The health of the land, bees, people and culture are all connected and happening across overlapping timescales, deeply embedded in ancestral time while also looking to the future.

In both Burning Vision and Chasing Honey, linear 'western' perceptions of time are troubled through ecological conditions which call forth the past, connecting it materiality with the present and future. This resistance to neo-liberal modes of time keeping, through non-linearity, may be considered part of an indigenous ecological ethos in performance.

\section{Ecojustice}

Maufort (2014) identifies ecojustice (the intersection of environment and social justice) as part of the aesthetics of ecology in contemporary indigenous drama. Interconnected with 
the nonlinearity and inseparability aspects of indigenous cosmologies, social justice issues are recognized as having ecological implications. If the more-than-human world is intimately intertwined with the human, and the material impacts of the past and present are felt in the future, ecological injustices, such as the exploitation of resources for humans, become insupportable. Recent plays and performances by non-indigenous theatre-makers have addressed some timely issues of ecojustice. For example, Oil City (2013) by Platform and Mel Evans (part of the ArtsAdmin Two Degrees Festival, London) included a First Nations activist character who wanted to draw attention to the way in which the Alberta tar sands development has effected the home, land and culture of her people.

Silav (2014) by Chantal Bilodeau (which premiered at Underground Railway Theater in Boston) considers the ecojustice issue of climate change effects on the Arctic (including opening up the Northwest Passage as an international trade route now that the ice pack has melted). The play is named after the Inuit idea of silavi, the spiritual relationship between people, climate and ecological processes, or 'breath', and considers it in relation to the politics of climate change and the Arctic. One of the main characters is an Inuit climate change activist modelled on real-life Inuk climate change advocate Shelia WattCloutier. Within the play, we see the how the Inuit are trying to raise global alarms about the melting polar ice and the effects of climate change on their culture and livelihoods. The Inuit are disproportionately affected by climate change despite their relatively small contribution to it. Watt-Cloutier argues that 'the Arctic is seen as a global barometer for climate change, and Inuit are responsible sentinels that have reached out to warn the world about this important issue that interconnects all of humanity' (Cape Farewell 2013: 31). Bilodeau writes her version of the Inuit activist as an international figure trying to draw the attention of the world to the Arctic, while faced with government inaction. The loss of land and culture of the Inuit is explored through Inuit mythology, such as the story of Nuliajuk, goddess of the ocean and underworld. The behaviour and lifestyles of the western world ostensibly have profound socio-ecological impacts on the Arctic and the Inuit who live there, yet it remains a 'foreign' and distant reality while the warnings and ecological knowledge of the Inuit are ignored or overlooked by policy makers. This lack of action could be seen as reinforcing colonial assumptions of 'otherness' and 'primitivism', invoking the eco-Indian trope to code the Inuit knowledge (Inuit Qaujimatuqangit) as 'naïve' and therefore inconsequential to contemporary society. By the end of the play, despite dealing with death, loss and hardships, the Inuit community members realize their fight for ecological justice is far from over. This commitment may be read as an 
understanding of ecojustice as part of what it means to live in the context of global climate change and indigenous marginalization.

Ecological and social justice issues have long been intertwined for indigenous peoples, having faced different cycles of loss since colonization. Scholar John Barry (2012) argues that the loss of traditional life of the Crow nation of Turtle Island, as depicted in Jonathan Lear's Radical Hope (2006), offers insights into ways of dealing with the possibility of ecological collapse. Lear refers to the 'narrative rupture' that occurs when 'settled and established ways of life, modes of thinking and acting collapse' (Barry 55). This collapse is not only in terms of the relationship to the ecological material world but is also psychological and social, as it disrupts world-views. Climate change has rendered all of humanity as 'vulnerability', having to face up to the possibility of collapse. By naming this shared vulnerability, and living with it, Barry argues that we can develop resilience. Acknowledging the 'narrative rupture' can also be a strategy for thinking of new modes of being and living within the ecology of the world. Ecojustice, within performance, may address this vulnerability and imagine different ways of resilience.

\section{Conclusion}

Environmental historian and postcolonial scholar Dipesh Chakrabarty (2012) contends art can 'extend our understanding to those who in future may suffer the impact of the geophysical force that is the human' (12). Stories in performance and the performance of stories may help our understanding of the material effects of climate change across multiple timescales, refracted through indigenous ecological knowledges. Acknowledging difference while understanding commonalities, particularly in the global effects of climate change is at the heart of an indigenous ethos in performance.

There are certainly other strategies for locating an Indigenous ecological ethos in performance that could be theorized, including what Däwes and Maufort term 'ecospirituality or 'that aspect of ecocriticism dealing with the spiritual bond between Indigenous people and the Earth' (14). Dreaming, language, place relationships and the role of the trickster could also be thought of in relation to an indigenous ethos as they are just some of ways that indigenous epistemologies are different than western-centric ones. ${ }^{\text {vii }}$ DeLoughrey and Handley (2011) write that the challenge of postcolonial ecology is 'to find a way to speak in ethical terms about the global and the local without reducing difference and without instituting old structural hierarchies; indeed we might say that this is 
the same challenge posed by global climate change' (25). Considering indigenous ecological strategies and dramaturgies will help performance and ecology develop into a more complex, relational and multivocal field.

Postcolonial ecology has just begun to be taken up by the western academy and the field of performance and ecology. The ethical demand and imperative exists for broadreaching acknowledgements that in themselves reflect the diversity of knowledge and interconnections between ecological subjugation and indigenous oppression, while not appropriating marginalized voices. To seriously consider and reciprocally enact these connections, and their material impacts, requires engagement from indigenous and nonindigenous scholars alike: avoiding patronising codification or romanticised tropes. We must recognize that framing an indigenous ethos, as a plurality, is a process in continuous flux, in which settler/indigenous thinkers seek out non-hierarchical ways of engaging heterogeneous forms of knowledge within the academy. This ethos provides a critique of the western hegemonic ecological assumptions based in western philosophy and opens up performance and ecology in a more inclusive and diverse way.

\section{References:}

Abram, D. (1997) The Spell Of The Sensuous: Perception And Language In A More-ThanHuman World, New York: Vintage Books.

Adamson, J. (2001) American Indian Literature, Environmental Justice, And Ecocriticism: The Middle Place, Tucson: University of Arizona Press.

Armstrong, J.C. (1998) 'Land Speaking' in S. J. Ortiz (ed.) Speaking For The Generations: Native Writers On Writing, Sun Tracks, Tucson: University of Arizona Press, pp. 174-195.

Barry, J. (2012) The Politics of Actually Existing Unsustainability: human flourishing in a climate-changed, carbon constrained world, New York: Oxford University Press, USA.

Bilodeau, C. (2014) Sila, Boston: Underground Railway Theater. (unpublished)

Byrd, J.A. (2006) '(Post) Colonial Plainsongs: Towards Native Literary Worldlings' in D. T. Jacobs (ed.) Unlearning The Language Of Conquest: Scholars Expose Anti-Indianism In America, Austin: University of Texas Press, pp. 81-93.

Cape Farwell. (2013) Climate is Culture (exhibition programme), Toronto: Royal Ontario Museum.

Chakrabarty, D. (2012) 'Postcolonial Studies and the Challenge of Climate Change', New Literary History, 43:1, pp. 1-18.

Clements, M.H. (2003) Burning Vision, Vancouver: Talonbooks. 
Däwes, B. (2014) 'Stages Of Resilience: Heteroholistic Environments In Plays By Marie Clements And Yvette Nolan' in B. Däwes \& M. Maufort (eds.) Enacting Nature: Ecocritical Perspectives On Indigenous Performance, Brussels: P.I.E. Peter Lang, pp. 21-46.

Däwes, B. \& Maufort, M. (eds.) (2014) Enacting Nature: Ecocritical Perspectives On Indigenous Performance, Brussels: P.I.E. Peter Lang.

DeLoughrey, E.M. \& Handley, G.B. (eds.) (2011) Postcolonial Ecologies: Literatures Of The Environment, New York: Oxford University Press.

Grande, S. (2004) Red Pedagogy: Native American Social And Political Thought, Lanham: Rowman \& Littlefield Publishers.

Gray, N. (2012) 'Bringing Blood To Ghosts: English Canadian Drama And The Ecopolitics Of Place' in W. Arons \& T.J. May (eds.) Readings In Performance And Ecology, New York: Palgrave Macmillan, pp. 23-32.

Halba, H. (2014) 'Cleansing The Tapu. Nature, Landscape And Transformation In Three Works By Māori Playwrights' in B. Däwes \& M. Maufort (eds.) Enacting Nature: Ecocritical Perspectives On Indigenous Performance, Brussels: P.I.E. Peter Lang, pp. 219-234.

Howe, L. (1999) 'Tribalography: The Power Of Native Stories', Journal Of Dramatic Theory And Criticism, XIV: 1, pp. 117-126.

Huggan, G. \& Tiffin, H. (eds.) (2010) Postcolonial Ecocriticism: Literature, Animals, Environment, London, New York: Routledge.

Kingsley, J., Townsend, M., Henderson-Wilson, C. \& Bolam, B. (2013) 'Developing An Exploratory Framework Linking Australian Aboriginal Peoples' Connection To Country And Concepts Of Wellbeing', International Journal Of Environmental Research And Public Health, 10: 2, pp. 678-698.

Knowles, R. P. \& Mojica, M. (eds.) (2003) Staging coyote's dream: an Anthology of First Nations drama in English, 1st ed. Toronto: Playwrights Canada Press.

Knowles, R. (2014) 'Mounds, Earthworks, Side Show Freaks And Circus Injuns' in Däwes, B. \& Maufort, M. (eds.) Enacting Nature: Ecocritical Perspectives On Indigenous Performance, Brussels: P.I.E. Peter Lang, pp. 47-58.

Krech, S. (1999) The Ecological Indian: Myth And History, New York: W.W. Norton \& Co.

Kuppers, P. (2014) 'Edges Of Water And Land: Transnational Performance Practices In Indigenous/settler Collaborations', Journal Of Arts \& Communities, 6: 1, pp. 5-28.

Lear, J. (2006) Radical Hope: ethics in the face of cultural devastation. Cambridge, Mass: Harvard University Press.

Leduc, T.B. (2010) Climate, Culture, Change: Inuit And Western Dialogues With A Warming North, Ottawa: University of Ottawa Press.

Luna, V. (2014) NK 603: Action For Performer \& E-Maiz (performance), in Australasian Association for Theatre Drama and Performance Studies (ADSA), Restoring Balance: Ecology, Sustainability, Performance, Wellington, New Zealand, 26-18 June.

(2014b) 'Body In Action: Cartographies For Socially Engaged Performance', in Australasian Association for Theatre Drama and Performance Studies (ADSA), Restoring Balance: Ecology, Sustainability, Performance, Wellington, New Zealand, 26-18 June. 
Maufort, M. (2014) 'Aesthetics Of Ecology In Contemporary Indigenous Drama' in B. Däwes \& M. Maufort (eds.) Enacting Nature: Ecocritical Perspectives On Indigenous Performance, Brussels: P.I.E. Peter Lang, pp. 235-254.

May, T.J. (2010) 'Kneading Marie Clements' Burning Vision', Canadian Theatre Review, 144: 1 , pp. 5-12.

---- (2014) 'Indigenous Theatre In Global Times: Situated Knowledge And Ecological Communities In Salmon Is Everything And Burning Vision' in R.D. Besel \& J.A. Blau (eds.) Performance On Behalf Of The Environment, Lanham: Lexington Books.

---- (2014b) Salmon Is Everything: Community-based Theatre In The Klamath Watershed, Corvallis: Oregon State University Press.

Mukherjee, P. (2011) 'Surfing the Second Waves: Amitav Ghosh's Tide Country', in Liam Connell \& Nicky Marsh (eds.) Literature and Globalization: a reader. London; New York: Routledge. pp. 177-189.

Nolan, Y. (2014) 'The Collapse Of Worlds In Laura Shamas's Chasing Honey' in Däwes, B. \& Maufort, M. (eds.) Enacting Nature: Ecocritical Perspectives On Indigenous Performance, Brussels: P.I.E. Peter Lang, pp. 105-115.

Plumwood, V. (2002) Environmental Culture: The Ecological Crisis Of Reason, London, New York: Routledge.

Smith, L.T. (2012) Decolonizing Methodologies: Research And Indigenous Peoples, Second Edition, London: Zed Books.

Stanlake, C. (2009) Native American Drama: A Critical Perspective, Cambridge, UK; New York: Cambridge University Press.

\section{Biographical Note:}

Lisa Woynarski is a performance-maker, researcher, and ecodramaturg working at the intersection of performance and ecology. Currently a PhD candidate at Central School of Speech \& Drama, her research articulates an ecological performance aesthetic, theorizing the way performance may engage, critique and highlight ecological relationships. Her current practice explores the making of ecological performance through site-based urban interventions. She makes research-engaged performances exploring questions of our relationship to the environment, climate change resilience and the phenomenological experience of socio-ecological relations.

Notes:

\footnotetext{
${ }^{1}$ I use the term indigenous in its global usage. When referring to specific tribes, nations, cultures, I follow the author's usage, including capitalizing 'indigenous' in direct quotations.

${ }^{2}$ I use the term 'more-than-human' to resist the binary between human/nonhuman (following Abram 1996).
} 
${ }^{\text {iii }}$ Here I am specifically referring to the system of knowledge production and legitimation, rather than individual scholars. This is not to dismiss the work the indigenous scholars within the western academy or the respectful work done by non-indigenous scholars in this area (including many fruitful settler/indigenous collaborations).

${ }^{3}$ Ric Knowles' (2003 with Mojica Monique, 2014) work is also particularly pertinent to Indigenous/non-Indigenous performance collaborations.

${ }^{4}$ I have written about Sila and Oil City for RiDE: the Journal of Applied Theatre and Performance, 'Ecological sentinels: Indigenous heroes or colonial cliché?' (June 2015).

${ }^{5}$ The Inuit concept of sila, which ascribes consciousness to climate, weather and other ecological processes, and could be translated in a number of different ways including 'a spiritual reference that is meant to contextualize the physicality of human relations within broader ecological processes like the weather' (Leduc 2010: 27).

${ }^{6}$ There are also more performance examples than could be cited here including Tompson Highway's Ernestine Shuswap Gets her Trout (2004), Yvette Nolan's The Unplugging (2012), Taki Rua's Ngunguru I Te Ao I Te Po (2014), Eddie Ladd's Dawns Ysbrydion/Ghost Dance (2013) and many more. 